\title{
TESTATE AMOEBAE AS PALAEOHYDROLOGICAL PROXIES IN SÜRMENE AĞAÇBAŞI YAYLASI PEATLAND (NORTHEAST TURKEY)
}

\author{
Richard J. Payne ${ }^{1}$, Dan J. Charman ${ }^{2}$, Sean Matthews ${ }^{2}$, Warren J. Eastwood ${ }^{3}$ \\ ${ }^{1}$ The Fitch Laboratory, British School at Athens \\ Odhós Souidhías 52, 10676 Athina, Greece \\ and \\ Geography, School of Environment and Development, The University of Manchester \\ Oxford Road, Manchester, M13 9PL, United Kingdom \\ E-mail: r.j.payne@manchester.ac.uk \\ ${ }^{2}$ School of Geography, University of Plymouth, Drake Circus \\ Plymouth, Devon, PL4 8AA, United Kingdom. \\ ${ }^{3}$ School of Geography, Earth and Environmental Sciences, The University of \\ Birmingham \\ Edgbaston, Birmingham, B15 2TT, United Kingdom
}

\begin{abstract}
Testate amoebae are unicellular micro-organisms whose hydrological sensitivity and good preservation in peats make them valuable proxies for past peatland surface wetness, and therefore climate. Previous testate amoebae transfer functions have been spatially restricted with no studies from Asia. To derive a transfer function, a sequence of samples was extracted from an ombrotrophic peatland in Turkey and amoebae counted. The internal structure of the data was explored using principal components analysis and relationships with the environmental data tested by redundancy analyses. Transfer function models were developed using a variety of techniques. As in other regions, depth to water table is the most important control on amoebae community composition. Transfer function performance was initially poor, primarily due to the inclusion of samples from areas of the site that had been heavily affected by peat cutting and had distinctly different amoebae communities. Model performance is improved by selective sample exclusion, reducing jack-knifed root mean square error of prediction to $7.1 \mathrm{~cm}$. The model was tested using an initial palaeoecological data-set. Overlap with the training set was limited, although a hydrological reconstruction using this model produces similar results to a transfer function derived from northern European peatlands. This study provides the first testate amoebae transfer function from Asia and demonstrates that hydrological preferences of many of the key taxa are consistent across a large area of the Northern Hemisphere. The transfer function will allow detailed palaeoclimate reconstruction from this peatland, adding to our knowledge of Holocene climatic change in southwest Asia.
\end{abstract}

Key Words: Asia Minor, Paleoclimate, Protists, Transfer function

\section{INTRODUCTION}

Peatlands have been shown to archive a continuous, reliable and high-resolution climatic record that has been validated by comparisons among sites, with other proxy records and with instrumental records for the recent past (Baker et al. 1999, Blackford 
2000, Charman and Hendon 2000, Hendon et al. 2001, Charman et al. 2004, 2006, Schoning et al. 2005). Studies attempt to reconstruct the palaeohydrology of peatlands, which in ombrotrophic systems is largely determined by the balance between precipitation and evapotranspiration. One of the most important advantages of peatlands as sources of Holocene palaeoclimatic data is their distribution, covering vast areas of the mid to high-latitudes and occurring in isolated locations at altitude around the world. This distribution allows the potential to develop globally integrated networks of Holocene climate records. However, this potential has not been well exploited to date. Studies have concentrated on temperate peatlands in northern and central Europe, North America, and in a small number of locations in New Zealand and South America (Wilmshurst et al. 2003, Mauquoy et al. 2004). In particular, peatland archives have been relatively underexploited in regions that are climatically marginal for ombrotrophic peat growth, where records are likely to be highly sensitive to climatic fluctuations.

In Turkey and the eastern Mediterranean region as a whole, there is meteorological evidence for climatic change since the early twentieth century (Türkeş and Sümer 2004, Türkeş et al. 2007). However, longer-term reconstructions of climate change in the Holocene are of limited number and are spatially and temporally restricted (Bar-Matthews et al. 1998, Goodfriend 1999, Schilman et al. 2001, Stevens et al. 2001, Roberts et al. 2001, 2004, Kashima 2002, Wick et al. 2003, Jones et al. 2005, 2006, Eastwood et al. 2007). Due to generally unfavourable climatic conditions for peat formation and human destruction of mires, Turkish peatlands are rare, covering perhaps $30 \mathrm{Km}^{2}$ (Çayci et al. 1988, Öz 1996, Byfield and Özhatay 1997). The majority of Turkish peatlands are minerotrophic fens; such ecosystems are considered sub-optimal for palaeoclimate research due to the less direct relationship between climate and peatland hydrology. One large ombrotrophic mire (Sürmene Ağaçbaşı Yaylası peatland) is present with a maximum recorded peat depth of $3.7 \mathrm{~m}$ and a good potential to develop a regional climate record.

One of the most well established techniques for palaeoclimatic reconstruction from peatlands is testate amoebae analysis. Testate amoebae are unicellular microorganisms (protists) that are sensitive indicators of hydrological conditions and are found preserved in peat. The methodology has been particularly developed through the use of transfer function models, which use testate amoebae species data to quantitatively infer water table change over time. These quantitative hydrological reconstructions contrast with the qualitative or at best semi-quantitative reconstructions of peatland surface wetness provided by other techniques such as macrofossil or humification analysis.

Testate amoebae are found in peatlands around the world and although amoebae species may not be entirely cosmopolitan, there is a good deal of similarity in species composition between widely separated sites (Wilkinson 2001, Charman 2001). The hydrological preferences of many taxa are well known and appear consistent across broad geographic regions (Booth and Zygmunt 2005). However, there are notable differences in community composition between studies, and there are several important taxa whose hydrological preferences are still inadequately understood. There have been no previous quantitative studies of testate amoebae in the peatlands of Turkey or Southwest Asia. As the region lies on a different continent from previous studies it is possible that the site may contain amoebae assemblages, and possibly amoebae taxa, not commonly encountered in previous transfer function studies. A study of the modern ecology of 
testate amoebae in this site and the development of a transfer function model is therefore an essential pre-requisite to palaeoecological study. The aims of this study are to investigate the testate amoebae community of Sürmene Ağaçbaşı Yaylası peatland, test the hydrological control of amoebae community structure, develop a transfer function model to allow palaeoenvironmental reconstruction, test this model using an initial palaeoecological data-set, and compare the results to those of previous studies.

\section{SITE AND METHODS}

Sürmene Ağaçbaşı Yaylası peatland is a large (c. 20 ha) ombrotrophic mire located in northeast Turkey $\left(40^{\circ} 6^{\prime} \mathrm{N}, 40^{\circ} 34^{\prime} \mathrm{E}\right), 40 \mathrm{~km}$ southeast from Trabzon, the regional capital and $10 \mathrm{~km}$ south of the Black Sea (Figure 1). The site lies at $2100 \mathrm{~m}$ asl. in the Soğanlı Dağ Mountains. Vegetation of the peatland includes Sphagnum fuscum, $S$. palustre., Carex spp., and Nardus stricta (Byfield and Özhatay 1997). Other plants noted in the field included Vaccinium uliginosum, Potentilla spp., and bryophytes including Leucobryum glaucum, Rhytidiadelphus squarrosus, and Polytrichum longisteum. The site has been affected by manual peat cutting over at least the last 30 years; cut peat holes are present across much of the site (Payne et al. 2007). Samples were extracted in August 2006 and were taken from three closely adjacent but hydrologically separate peat areas divided by a road and meadowland (Figure 1). These areas are referred to as the eastern, western, and southern sectors; it is unclear whether all three peat areas were once connected. The majority of the samples (38) were taken from the western sector of the site, which has been affected by peat cutting but is generally more intact than the other areas. Smaller numbers of samples were taken from the eastern (8) and southern (7) sectors.

At each sampling point a block of peat approximately $5 \times 5 \times 5 \mathrm{~cm}$ was removed from the surface layer. Water table depth was measured by making a small hole adjacent to the sampling point and depth to water table (DWT) measured after leaving the sampling site overnight for the water table to equilibrate. Samples were returned to the laboratory and moisture content and loss on ignition measured by drying the sample at $110^{\circ} \mathrm{C}$ and then incinerating at $550^{\circ} \mathrm{C}$. A $2 \mathrm{~cm}^{3}$ sub-sample was taken from the uppermost $3 \mathrm{~cm}$ of the sampling block, disaggregated in $50 \mathrm{ml}$ distilled water and $\mathrm{pH}$ measured after one hour. Amoebae were extracted by boiling the sample and then sieving at 15 and 300 $\mu \mathrm{m}$ with the 15>300 $\mu \mathrm{m}$ fraction retained (Hendon and Charman 1997). Slides were prepared by mixing this material with glycerol and examined at $400 \mathrm{X}$ magnification. A minimum of 150 amoebae were identified using a range of taxonomic literature (Corbet 1973, Ogden and Hedley 1980, Ogden 1983, Ellison and Ogden 1987, Charman et al. 2000, Clarke 2003). Taxonomy broadly follows Charman et al. (2000) with the exception of a few types that were subdivided: Cyclopyxis arcelloides type (into Cyclopyxis arcelloides, Cyclopyxis eurystoma, and Phryganella acropodia), Corythion-Trinema type (into Corythion dubium, Trinema complanatum, and Trinema enchelys), Nebela tubulosa type (into Nebela tubulosa and Nebela penardiana), and Nebela tincta type (which was not differentiated from similar taxa without pores). The taxa referred to as Arcella catinus type and Centropyxis cassis type by Charman et al. (2000) are referred to here as Arcella arenaria type and Centropyxis aerophila type reflecting the dominant species.

Ordination was used to investigate the community structure and relationships with the environmental data. As an initial detrended correspondence analysis (DCA) showed 
the compositional gradient to be short ( $<3 \mathrm{SD}$ ), linear methods were more appropriate than their unimodal equivalents. The structure of the data was initially investigated using principal components analysis (PCA) with taxa occurring in four or fewer samples excluded and data log-transformed. The environmental controls on amoebae communities were investigated using redundancy analysis (RDA) with significance testing by Monte Carlo permutation tests (999 permutations). All ordination analyses were carried out in Canoco version 4.53 (ter Braak and Šmilauer 1997-2004).

Transfer function models were developed using weighted average (WA), weighted average partial least squares (WA-PLS), maximum likelihood (ML), partial least squares (PLS), and modern analogue techniques (MAT; Birks 1995) in $\mathrm{C}^{2}$ version 1.3 (Juggins 2003). Root mean square error of prediction (RMSEP) was used as the primary indicator of model performance, this was estimated using both jack-knife and boot-strap techniques (1000 cycles). As model performance was initially poor (see results section), data selection was used to improve performance. Taxa occurring in few samples were initially removed; subsequently samples for which the model performed poorly were removed. The samples that were removed were selected using an iterative methodology with residuals re-calculated after every successive phase of data filtering (Payne et al. 2006).

As a test of the efficacy of the transfer function for palaeoenvironmental inference, two of the best-performing models were applied to a sequence of palaeoecological samples. A core was extracted from an uncut area of the western sector of the site and samples extracted every $8 \mathrm{~cm}$. Samples were prepared following Hendon and Charman (1997) and amoebae identified using Charman et al. (2000); a count of 100 tests was targeted. The transfer function was adjusted to account for slight differences in taxonomic approach. The Cycolopyxis arcelloides, Cyclopyxis eurystoma, and Phryganella acropodia types were grouped in the modern data and the Nebela tincta and Nebela parvula types in the palaeoecological data. As a separate test, a transfer function derived from peatlands in northern Europe was also applied (Charman et al. 2007).

\section{RESULTS}

A total of 8,295 amoebae were counted, the most abundant taxa were Assulina muscorum (30\% of total count) and Hyalosphenia papilio (25\%; Table 3). Distinct differences were noted between the southern and eastern and the western sectors of the peatland; in particular $H$. papilio was highly abundant in the western sector (35\% of total) but was totally absent in the other two areas. The PCA plot (Figure 2) illustrates these differences, with southern and eastern sector samples generally having low scores on axis one and high scores on axis two. RDA shows all the environmental data (DWT, percent moisture, $\mathrm{pH}$, LOI and site sector nominal variables) explain $39 \%$ of variance ( $\mathrm{P}<$ $0.001)$. Depth to Water Table alone explained $16 \%$ of variance $(\mathrm{P}<0.001)$. With LOI and $\mathrm{pH}$ partialled out DWT explained $9.4 \%$ of variance $(\mathrm{P}<0.001)$.

Using the full data, transfer function model performance was poor with an

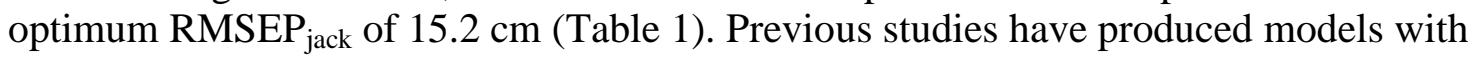
$\mathrm{RMSEP}_{\text {jack }}$ values below $10 \mathrm{~cm}$. A plot of model predictions against measured values (Figure 3) shows that model performance was particularly poor for some samples at the ends of the water table gradient, and especially one sample (SAY 59) with a water table depth much greater than any of the other samples. 
Data selection was used to improve performance of the model. Removing rare taxa resulted in an increase in RMSEP but removing samples with high residuals produced a consistent improvement in model performance. Samples with residuals greater than $14 \mathrm{~cm}$ were removed from the data set, reducing $\mathrm{RMSEP}_{\text {jack }}$ to $7.1 \mathrm{~cm}$. This cut off point amounts to $9 \%$ of the total gradient, less than the $20 \%$ level applied in several previous studies (Charman 1997, Payne et al. 2006, Charman et al. 2007, Payne and Mitchell 2007); this is largely because the water table gradient was extended by the inclusion of the very dry sample SAY 59 (Table 2). Using data selection usually results in removal of samples from the extremes, reducing the length of the hydrological gradient and thereby reducing the applicability of the model. Here, excluding samples with residuals greater than $14 \mathrm{~cm}$ reduces the hydrological gradient by almost $50 \%$ from 154 to $79 \mathrm{~cm}$, but this is solely due to removing two samples from the very driest and very wettest locations. The total number of samples included in the model was reduced to 42 . Model performance was significantly poorer for the more disturbed eastern sectors of the site. The mean residual for the eastern samples was $13.9 \mathrm{~cm}$ compared to $6.9 \mathrm{~cm}$ for the western samples. The eastern sector samples are preferentially removed when filtering for high residuals (Table 2). Removing all samples from the eastern sectors of the site reduced $\mathrm{RMSEP}_{\text {jack }}$ by almost $50 \%$.

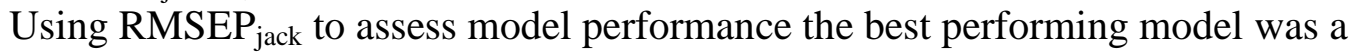
four component PLS model, but when using RMSEP boot $_{\text {to }}$ assess performance the best performing model was a ML model. After data filtering a ML model performed best by both measures. Maximum Likelihood models have rarely been tested in testate amoebae transfer function studies. They are distinct from weighted-average based models in that they attempt to directly model the species response curve, rather than approximating this using a weighted average (Birks 1995). The good performance of this model here and in another recent study (Payne and Mitchell 2007) suggest the approach should be more widely tested.

Both the ML and WA-PLS models were applied to a palaeoecological data set and results compared to reconstructions using a northern European transfer function (Charman et al. 2007; Figure 5). Overlap between the modern and palaeoecological data was sub-optimal. Only 14 of the 27 taxa in the palaeoecological data were included in the modern training set, although the exceptions were mostly more minor taxa. Between 70 and $100 \%$ of tests were included in the transfer function for each sample (mean 94\%). The most abundant taxa not included are Heleopera sphagni, Heleopera sylvatica, and Hyalosphenia elegans. This difference may be because the modern samples did not include the habitats of these taxa, or these taxa have been lost from the site in the past.

Generally similar trends were apparent with both ML and WA-PLS models (Figure 6). From the top of the sequence to $72 \mathrm{~cm}$ depth the ML model showed a gradual increase in values while WA-PLS showed short-term variability with no overall trend. From 72 to $120 \mathrm{~cm}$ there was a period of higher values. Following this, there was a short period of lower values followed by a resumed increase to a peak at $144 \mathrm{~cm}$ and a trough at $152 \mathrm{~cm}$. In the lower portions of the core the ML model showed few trends while the WA-PLS model showed a general increase in values. For the majority of samples, sample specific error estimates were lower with ML than with WA-PLS, supporting the model choice based on modern data. There was broad similarity with the results of the northern European transfer function. The most notable differences were that the northern European 
transfer function showed fluctuating values with little overall trend in the upper portions of the core (not shown by the ML model) and a declining trend of values at the base of the core (not shown by either site-specific model). Absolute values were higher with the site-specific model. Results of the WA-PLS model appeared more similar to the northern European transfer function than those of the ML model. This does not necessarily imply superiority; this may simply be due to the greater similarity in model structure.

\section{DISCUSSION}

The community compositions in our samples support previous studies in illustrating the cosmopolitan distribution of testate amoebae. The majority of testate amoebae taxa we encountered have frequently occurred in previous transfer function studies from Europe and North America. A few somewhat more unusual taxa are present such as Nebela tubulata, Sphenoderia fissirostris, Lesquereusia modesta, Lesquereusia epistomium, and Tracheleuglypha dentata. The presence of some of these taxa (particularly the Lesquereusia species) may be explained by the changes to the site through peat cutting. Lesquereusia species were predominantly found in wet, high-pH samples from the edge of cut holes in the peat surface. A notable absence was Nebela militaris, a taxon found in all previous transfer function studies, often in high abundance. Ordination results agree with those of previous studies using similar methodologies in showing hydrology to be the most important control on amoebae community composition. Redundancy analyses showed $9.4 \%$ of variance is independently explained by hydrology, comparable to the results of previous studies.

The hydrological optima of testate amoebae taxa (Table 3) showed a good deal of similarity to previous studies. At the wettest end of the gradient were taxa well known for their hydrophilic tendencies such as Centropyxis aculeata and Hyalosphenia papilio, while at the drier end were taxa believed to be xerophilic such as Trigonopyxis arcula and Trinema lineare. Of the more unusual taxa, Difflugia pulex type - an important taxon in many palaeoecological studies - was present in two samples from the drier end of the hydrological gradient (optima $71.7 \mathrm{~cm}$ ). Although this taxon was very rare its presence is interesting as it contrasts with the lower DWT optima found by Payne and Mitchell (2007) and Charman et al. (2007). Euglypha cristata had a relatively high DWT optima $(48.1 \mathrm{~cm})$ in contrast to the results from the small number of samples where it was found by Charman et al. (2007) but broadly similar to Payne and Mitchell (2007). Nebela tubulata is typical of moderately dry conditions while Lesquereusia modesta and Lesquereusia epistomium are both found in very wet locations.

Direct comparison of taxa optima with previous work was not possible as studies have adopted different measurement methodologies. All but one study have used onetime water table measurements so values largely reflect weather conditions just prior to the sampling time. Given this situation two approaches are possible to compare optima among studies. Firstly, it is possible to compare the relative positions of taxa optima on the overall hydrological gradient (Booth 2001, Lamentowicz and Mitchell 2005, Payne et al. 2006). Figure 4. shows a comparison of relative DWT optima with selected previous studies. Results for this study generally lie within the range of other studies with the exception of Centropyxis aculeata, which has a particularly low DWT optima, and Euglypha rotunda, which has a particularly high optima. This approach allows general 
comparisons of taxa hydrological preferences but is not ideal as there are real differences in the hydrological range covered by the studies.

An alternative approach is to examine the rank order of taxa on the hydrological gradient (Charman et al. 2000). Table 4 compares rankings between this study and 11 others from previous research in Northern Hemisphere peatlands. Taxa were selected that were present in all studies, were morphologically distinct with minimal opportunity for taxonomic confusion, and for preference, were single species and not groups which may complicate interpretation. Given the broad similarity in peatland types and the general ubiquity of protists, surprisingly few taxa are present in all studies with several common taxa such as Euglypha rotunda, Euglypha strigosa, and Nebela militaris absent from one or more study. The rankings in Table 4 show a good deal of similarity between studies with Centropyxis aculeata generally at the wetter end of the spectrum and Trigonopyxis arcula always indicating dry conditions. However there are exceptions. Hyalosphenia papilio, which most studies show to be an indicator of wet conditions, is the driest indicator in the Newfoundland study (Charman and Warner 1997). There is little consensus over the indicator value of Heleopera petricola, ranging from the second wettest indicator in Russia and Finland to the second driest in the British Isles (Bobrov et al. 1999, Tolonen et al.1994, Woodland et al.1998). The similarity between the rankings in this study and previous work can be tested quantitatively using Page's L test (Page 1963). Results demonstrate that the null hypothesis can be rejected; there is a significant relationship between the taxa ranks $(\mathrm{L}=2115, \mathrm{P}<0.001)$. Although the methodology is comparatively crude this result demonstrates the general similarity in hydrological preferences of the major testate amoebae taxa across a large region of the Northern Hemisphere spanning Alaska to western Russia and Asia Minor. Generally, we have a good knowledge of the hydrological preferences of taxa that are abundant and found at the extremes of the hydrological gradient. However, our knowledge of taxa that are rare or found in intermediate conditions is much poorer.

With the full data set the transfer function model performed comparatively poorly during both cross-validation and palaeoenvironmental reconstruction. This is largely the result of including samples from areas that have been subject to peat cutting. The PCA shows distinct differences between samples from the cut and uncut areas and samples from cut areas of the peatland are preferentially removed in data filtering. Samples were included from regenerating peat in abandoned cuttings and from uncut areas of peat that have been dried out as a result of cutting nearby. Testate amoebae communities from these habitats may not be as sensitive to hydrology as in pristine areas. In uncut areas the amoebae community may not have fully adjusted to the hydrological changes caused by cutting, particularly as samples will integrate amoebae from a period of several years. The plant communities and physical environment of regenerating peat are different from the uncut areas so the controls on amoebae communities may also be different from pristine areas.

Despite imperfect modern analogues, results of palaeoenvironmental reconstruction compare reasonably well with the northern-European model, adding further support to the broad similarity of amoebae hydrological preferences across the northern Hemisphere. Previous studies have used multiple sites to increase the probability of finding good modern analogues for palaeo-amoebae communities. As this is the only ombrotrophic Sphagnum peatland currently known in Turkey, there is no option to 
include additional sites here. In such instances, comparison with transfer functions from other regions provides a useful means to enhance confidence in the palaeoenvironmental reconstructions produced. These initial palaeoecological results cannot be used for palaeoclimatic inference in the absence of dating evidence. Future work will examine the amoebae palaeoecological record at higher resolution, employ other proxy-records, and radiocarbon date the profile.

\section{ACKNOWLEDGMENTS}

We would like to thank the Çevre ve Orman Bakanlığ 1 (Ministry for Environment and Forestry) for permission to work in northeast Turkey. This paper is a contribution to the ENV $\triangle$ NET (Environmental Change in Northeast Turkey) project funded by grants from the British Institute at Ankara, National Geographic Society, Royal Geographical Society, and University of Birmingham to WJE. The Dudley Stamp Memorial Fund provided additional fieldwork funding to RJP. RJP's work was primarily funded by a BSA MacMillan-Rodewald fellowship. Our thanks are extended to Dr Elizabeth Maher (Aberystwyth) and Professor Hakan Yiğitbaşioğlu (Ankara) for field assistance and to the British Institute at Ankara, Turkey for logistical support during fieldwork. Kevin Burkhill and Anne Ankcorn are also thanked for cartographic assistance. The paper benefited from the comments of three anonymous reviewers.

LITERATURE CITED

Baker, A., C. J. Caseldine, M. A. Gilmour, D. Charman, C. J. Proctor, C. J.

Hawkesworth, and N. Phillips 1999. Stalagmite luminescence and peat humification records of palaeomoisture for the last 2500 years. Earth and Planetary Science Letters 165:157-162.

Bar-Matthews, M., A. Ayalon, and A. Kaufman. 1998. Middle to Late Holocene (6,500 yr. period) paleoclimate in the Eastern Mediterranean region from stable isotopic composition of speleothems from Soreq Cave, Israel. In AS. Issar and N. Brown (eds.) Water, environment and society in times of climatic change. Kluwer, Dordrecht, The Netherlands.

Birks, H. J. B. 1995. Quantitative palaeoecological reconstructions. In D. Maddy and S. Brew (eds.) Statistical modelling of Quaternary science data. Quaternary Research Association, Cambridge, UK.

Blackford, J. 2000. Palaeoclimatic records from peat bogs. Trends in Ecology and Evolution 15:193-198.

Bobrov, A., D. Charman, and B. Warner. 1999. Ecology of testate amoebae (Protozoa: Rhizopoda) on peatlands in Western Russia with special attention to niche separation in closely related taxa. Protist 150:125-136.

Booth, R. K. 2001. Ecology of testate amoebae (protozoa) in two Lake Superior coastal wetlands: implications for palaeoecology and environmental monitoring. Wetlands 21:564-576.

Booth, R. K. 2002. Testate amoebae as paleoindicators of surface-moisture changes on Michigan peatlands: modern ecology and hydrological calibration. Journal of Paleolimnology 28:129-348.

Booth, R. K. and J. R. Zygmunt. 2005. Biogeography and comparative ecology of testate amoebae inhabiting Sphagnum -dominated peatlands in the Great Lakes and Rocky Mountain regions of North America. Diversity and Distributions 11:577-59. 
Byfield, A. and N. Özhatay. 1997. A future for Turkey's peatlands: a conservation strategy for Turkey's peatland heritage. Doğal Hayati Koruma Derneği, Istanbul, Turkey. Çayci, G., Y. Ataman, I. Ünver, and N. Munsuz. 1988. Distribution and horticultural values of the peats in Anatolia. Acta Horticulturae 238:189-196.

Charman, D. 1997. Modelling hydrological relationships of testate amoebae (Protozoa: Rhizopoda) on New Zealand peatlands. Journal of the Royal Society of New Zealand 27:465-83.

Charman, D. J. 2001. Biostratigraphic and palaeoenvironmental applications of testate amoebae. Quaternary Science Reviews 20:1753-1764.

Charman, D. and B. Warner. 1992. Relationship between testate amoebae (Protozoa: Rhizopoda) and microenvironmental parameters on a forested peatland in northeastern Ontario. Canadian Journal of Zoology 7:2474-2482.

Charman, D. and B. Warner. 1997. The ecology of testate amoebae (Protozoa:

Rhizopoda) and microenvironmental parameters in Newfoundland, Canada: modeling hydrological relationships for palaeoenvironmental reconstruction. Ecoscience 4:555562.

Charman, D. and D. Hendon. 2000. Long-term changes in soil water tables over the past 4500 years: relationships with climate and North Atlantic atmospheric circulation and sea surface temperatures. Climatic Change 47:45-59.

Charman, D., D. Hendon, and W. Woodland. 2000. The Identification of testate amoebae (protozoa: rhizopoda) from British oligotrophic peats. Quaternary Research Association Technical Guide Series, Cambridge, UK.

Charman, D. J., A. D. Brown, D. Hendon, A. Kimmel, and E. Karofeld. 2004. Testing the relationship between Holocene peatland palaeoclimate reconstructions and instrumental data. Quaternary Science Reviews 23:137-143.

Charman, D. J., A. Blundell, R. C. Chiverrell, D. Hendon and P. G. Langdon. 2006. Compilation of non-annually resolved Holocene proxy-climate records: stacked Holocene peatland palaeo-water table reconstructions from northern Britain. Quaternary Science Reviews 25:336-350.

Charman, D. J., A. Blundell, and ACCROTELM members. 2007. A pan-European testate amoebae transfer function for palaeohydrological reconstruction on ombrotrophic peatlands. Journal of Quaternary Science

Clarke, K. J. 2003. Guide to the Identification of Soil Protozoa - Testate Amoebae Special publication 12. Freshwater Biological Association, Ambleside, UK.

Corbet, S. A. 1973. An illustrated introduction to the Testate Rhizopods in Sphagnum, with special reference to the area around Malham Tarn, Yorkshire. Field Studies 3:801838.

Ellison, R. L. and C. G. Ogden 1987. A guide to the study and identification of fossil testate amoebae in Quaternary lake sediments. International Review of Hydrobiology 72:639-652.

Goodfriend, G. A. 1999. Terrestrial stable isotope records of Late Quaternary paleoclimates in the eastern Mediterranean region. Quaternary Science Reviews 18:501514.

Hendon, D. and D. Charman. 1997. The preparation of testate amoebae (Protozoa: Rhizopoda) samples from peat. The Holocene 7:199-205. 
Hendon, D., D. Charman, and M. Kent. 2001. Palaeohydrological records from testate amoebae analysis from peatlands in northern England: within-site variability, betweensite variability, between-site comparability and palaeoclimatic implications. The Holocene 11:127-148.

Jones, M. D., M. J. Leng, C. N. Roberts, M. Türkeş, and R. Moyeed. 2005. A Coupled Calibration and Modelling Approach to the Understanding of Dry-Land Lake Oxygen Isotope Records. Journal of Paleolimnology 34:391-411.

Jones, M. D., C. N. Roberts, M. J. Leng, and M. Türkeş. (2006) A high-resolution late Holocene lake isotope record from Turkey and links to North Atlantic and monsoon climate. Geology 34:361-364.

Juggins, S. 2003. C2 user guide. Software for ecological and palaeoecological data analysis and visualisation. University of Newcastle, Newcastle upon Tyne, UK.

Kashima, K. 2002. Environmental and climatic changes during the last 20,000 years at Lake Tuz, central Turkey. Catena 48:3-20.

Lamentowicz, M. and E.A.D. Mitchell. 2005. The ecology of testate amoebae (Protists) in Sphagnum in relation to peatland ecology. Microbial Ecology 50:48-63.

Mauquoy, D., M. Blaauw, B. van Geel, A. Borromei, M. Quattrocchio, F. M. Chambers, and G. Possnert. 2004. Late Holocene climatic changes in Tierra del Fuego based on multi-proxy analyses of peat deposits. Quaternary Research 61:148-158.

Mitchell, E., B. Warner, A. Buttler, and J-M. Gobat. 1999. Ecological patterns of testate amoebae (Protozoa) on peatlands in the Jura Mountains, Switzerland and France.

Ecoscience 6:565-576.

Ogden, C. G. 1983. Observations on the systematics of the genus Difflugia in Britain (Rhizopoda, Protozoa). Bulletin of the British Museum of Natural History (Zoology) 44:1-73.

Ogden, C. G. and R. H. Hedley 1980. An atlas of freshwater testate amoebae. British Museum (Natural History) and Oxford University Press, London and Oxford, UK. Öz, D. 1996. Peatlands in Turkey. In E. Lappalainen (ed.) Global Peat Resources. International Peat Society, Jyskä, Finland.

Page, E. B. 1963. Ordered hypotheses for multiple treatments: A significance test for multiple ranks. Journal of the American Statistical Association 58:216-230.

Payne, R., K. Kishaba, J. Blackford, and E. Mitchell. 2006. The ecology of testate amoebae in southcentral Alaskan peatlands: Building transfer function models for palaeoenvironmental inference. The Holocene 16:403-414.

Payne, R. and E. Mitchell. 2007. Ecology of testate amoebae from mires in the Central Rhodope Mountains, Greece and development of a transfer function for paleohydrological reconstruction. Protist 158:159-171.

Payne, R., W. Eastwood and D. Charman. 2007. The ongoing destruction of Turkey's largest upland mire by peat cutting. International Mire Conservation Group Newsletter $2007 / 1$. 
Roberts, N., J. M. Reed, M. J. Leng, C. Kuzucuoğlu, M. Fontugne, J. Bertaux, H. Woldring, S. Bottema, S. Black, E. Hunt, and M. Karabiyikoglu. 2001. The tempo of Holocene climatic change in the eastern Mediterranean region: new high-resolution crater-lake sediment data from central Turkey. The Holocene 11:721-736.

Schoning, K., D. J. Charman, and S. Wastegård. 2005. Reconstructed water tables from two ombrotrophic mires in eastern central Sweden compared with instrumental meteorological data. The Holocene 15:111-118.

Schilman, B., M. Bar-Matthews, A. Almogi-Labin, and B. Luz. 2001. Global climate instability reflected by Eastern Mediterranean marine records during the late Holocene. Palaeogeography, Palaeoclimatology, Palaeoecology 176:157-176.

Stevens, L. R., H. E. Wright Jr., and E. Ito. 2001. Proposed changes in seasonality of climate during the late-glacial and Holocene at Lake Zeribar, Iran. The Holocene 11:747756.

Ter Braak, C. and P. Šmilauer. 1997-2004. CANOCO for Windows. Biometris-Plant Research, The Netherlands.

Tolonen, K., B. Warner, and H. Vasander. 1994. Ecology of testaceans (protozoa:rhizopoda) in mires in Southern Finland: II multivariate analysis. Archiv fur Protistenkunde 144:97-112.

Türkeş, M. and U. M. Sümer. 2004. Spatial and temporal patterns of trends and variability in diurnal temperature ranges of Turkey. Theoretical and Applied Climatology 77:195-227.

Türkeş, M., U. M. Sümer, and G. Kiliç 2007. Variations and trends in annual mean air temperatures in Turkey with respect to climatic variability. International Journal of Climatology 15:557-569.

Warner, B. and D. Charman. 1994. Holocene changes on a peatland interpreted from testate amoebae (Protozoa) analysis. Boreas 23: 270-280.

Wick, L., G. Lemcke and M. Sturm. 2003. Evidence of Lateglacial and Holocene climatic change and human impact in eastern Anatolia: high-resolution pollen, charcoal, isotopic and geochemical records from the laminated sediments of Lake Van, Turkey.

The Holocene 13:665-675.

Wilkinson, D. 2001. What is the upper size limit for cosmopolitan distribution in freeliving microorganisms? Journal of Biogeography 28:285-291.

Wilmshurst, J., S. Wiser, and D. Charman. 2003. Reconstructing Holocene water tables in New Zealand using testate amoebae: differential preservation of tests and implications for the use of transfer functions. The Holocene 13:61-72.

Woodland, W., D. Charman, and P. Simms. 1998: Quantitative estimates of water tables and soil moisture in Holocene peatlands from testate amoebae. The Holocene 8:261-273. 
Table 1. Transfer function model performance for full and filtered data with model name abbreviations. Performance assessed by root mean square error of prediction (RMSEP), $\mathrm{R}^{2}$, and maximum bias (Max. Bias) estimated by boot-strap and jack-knife techniques. For the full data, additional components in WA-PLS did not outperform WA. Additional components in PLS and WA-PLS were only included if they reduced RMSEP by $>5 \%$. Numbers in bold indicate best performing model.

\begin{tabular}{|c|c|c|c|c|c|c|}
\hline \multicolumn{7}{|c|}{ Model structures } \\
\hline WA-Tol & \multirow{5}{*}{\multicolumn{6}{|c|}{$\begin{array}{l}\text { Weighted average (tolerance downweighting, inverse deshrinking) } \\
\text { Weighted average partial least squares (optimum number of components) } \\
\text { Maximum likelihood } \\
\text { Partial least squares (optimum number of components) } \\
\text { Modern analogue technique (weighted average of } 10 \text { closest analogues) }\end{array}$}} \\
\hline WA-PLS & & & & & & \\
\hline & & & & & & \\
\hline PLS & & & & & & \\
\hline WMAT & & & & & & \\
\hline \multicolumn{7}{|c|}{ 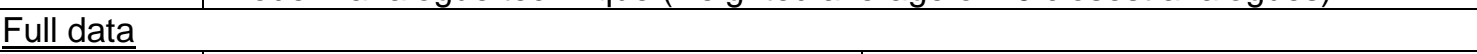 } \\
\hline & \multicolumn{3}{|c|}{$\begin{array}{l}\text { Jack-knife (leave-one-out) cross } \\
\text { validation }\end{array}$} & \multicolumn{3}{|c|}{ Boot-strap cross validation } \\
\hline & RMSEP & $\mathrm{R}^{2}$ & Max Bias & RMSEP & $\mathrm{R}^{2}$ & Max Bias \\
\hline WA-Tol & 16.6 & 0.49 & 96.7 & 17.0 & 0.53 & 95.3 \\
\hline$\overline{M L}$ & 16.5 & 0.50 & 78.4 & 16.5 & 0.58 & 79.6 \\
\hline PLS & 15.2 & 0.58 & 83.9 & 17.1 & 0.59 & 81.4 \\
\hline WMAT & 17.6 & 0.45 & 89.2 & 18.6 & 0.45 & 89.3 \\
\hline \multicolumn{7}{|c|}{ Filtered data } \\
\hline$\overline{\text { WA-Tol }}$ & 8.7 & 0.71 & 20.2 & 9.1 & 0.73 & 16.0 \\
\hline WA-PLS & 7.6 & 0.78 & 25.2 & 8.3 & 0.78 & 25.0 \\
\hline $\mathrm{ML}$ & 7.1 & 0.81 & 21.7 & 8.1 & 0.82 & 21.3 \\
\hline PLS & 7.6 & 0.78 & 27.9 & 8.9 & 0.77 & 28.5 \\
\hline WMAT & 10.4 & 0.6 & 24.7 & 10.8 & 0.6 & 24.5 \\
\hline
\end{tabular}


Table 2. Samples removed from data set when filtering for high residuals and possible reasons for poor model performance.

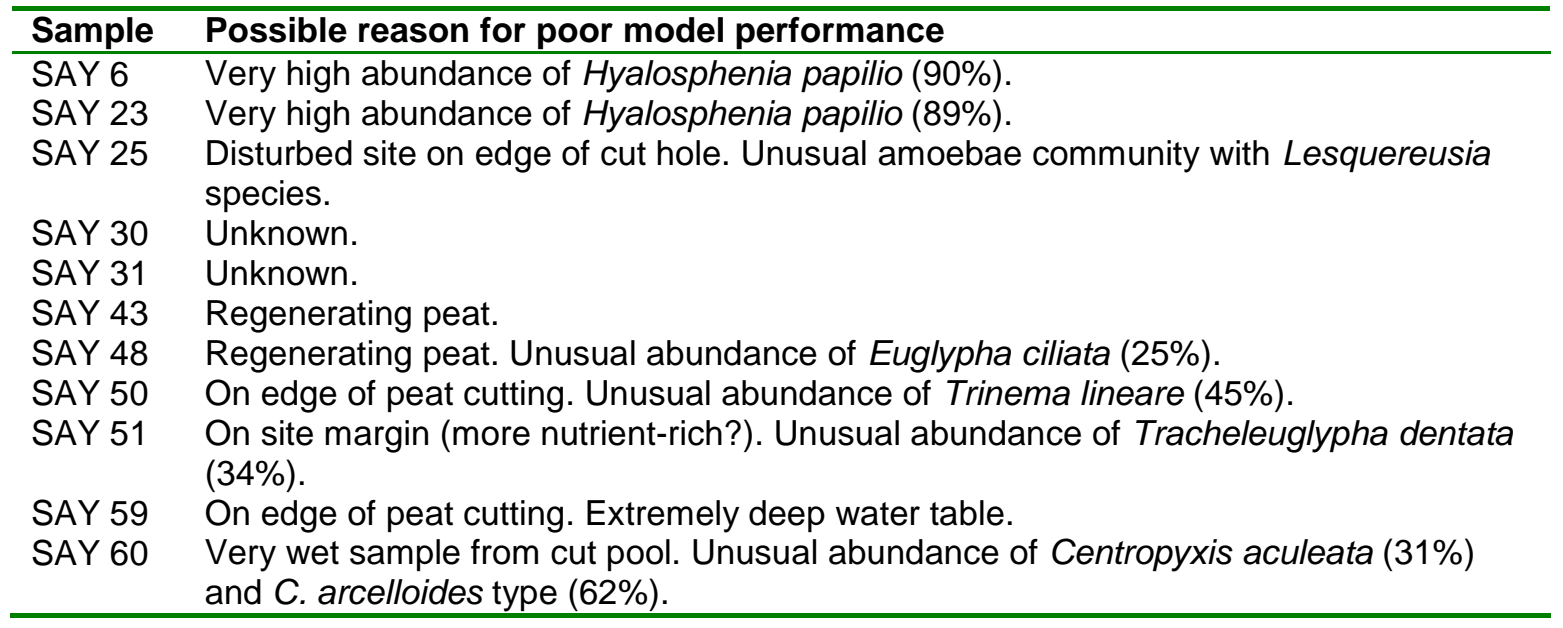


Table 3. Taxa encountered in this study, abbreviations used, number of occurrences $(\mathrm{N})$, maximum abundance, hydrological optima, and hydrological tolerances calculated by

weighted averaging.

Taxon

Arcella arenaria Greef 1866 type

Amphitrema flavum (Archer 1877)

Assulina muscorum Greef 1888

Assulina seminulum Ehrenberg 1848

Centropyxis aculeata (Ehrenberg 1830)

Centropyxis aerophila Deflandre 1929

type

Centropyxis ecornis (Ehrenberg 1841)

Corythion dubium Taranek 1881

Cryptodifflugia oviformis Penard 1890

Cyclopyxis arcelloides (Leidy 1879) type

Cyclopyxis eurystoma (Deflandre 1929)

type

Difflugia oblonga Ehrenberg 1838

Difflugia pulex Penard 1902 type

Difflugia rubescens Penard 1891

Euglypha ciliata (Ehrenberg 1848)

Euglypha compressa Carter 1864

Euglypha cristata Leidy 1874

Euglypha rotunda Wailes 1911

Euglypha strigosa (Ehrenberg 1872)

Heleopera petricola Leidy 1879

Heleopera rosea Penard 1890

Heleopera sylvatica Penard 1890

Hyalosphenia papilio Leidy 1875

Lesquereusia epistomium Penard 1902

Lesquereusia modesta Rhumber 1895

Nebela dentistoma Penard 1890

Nebela penardiana Deflandre 1936

Nebela tincta (Leidy 1879) type

Nebela tubulata Brown 1911

Nebela tubulosa Penard 1890

Phryganella acropodia (Hertwig and

Lesser 1874) type

Plagiopyxis cf. callida Penard 1910

Quadrulella symmetrica Wallich 1863

Sphenoderia cf. fissirostris Penard 1890

Tracheleuglypha dentata Moniez 1888

Trinema complanatum Penard 1890

Trinema enchelys Ehrenberg 1838

Trinema lineare Penard 1890

Trigonopyxis arcula (Leidy 1879)

Habrotrocha angusticollis Murray $1905^{1}$ analyses here.

\begin{tabular}{|c|c|c|c|}
\hline $\mathbf{N}$ & $\begin{array}{c}\text { Maximum } \\
\text { Abundance } \\
(\%)\end{array}$ & $\begin{array}{l}\text { Optima } \\
\text { (cm) }\end{array}$ & $\begin{array}{c}\text { Tolerance } \\
\text { (cm) }\end{array}$ \\
\hline 7 & 2 & 55.6 & 21.8 \\
\hline 3 & 1 & 25.6 & 10.3 \\
\hline 52 & 74 & 47.7 & 21.8 \\
\hline 41 & 75 & 43.9 & 10.2 \\
\hline 3 & 31 & 0.6 & 2.5 \\
\hline 26 & 15 & 64.0 & 36.1 \\
\hline 1 & 1 & 55.0 & - \\
\hline 39 & 32 & 47.5 & 17.7 \\
\hline 20 & 33 & 36.5 & 8.1 \\
\hline 5 & 62 & 1.5 & 9.0 \\
\hline 10 & 13 & 84.3 & 39.9 \\
\hline 1 & 1 & 12.0 & - \\
\hline 2 & 2 & 71.7 & 9.2 \\
\hline 2 & 1 & 8.9 & 6.4 \\
\hline 18 & 25 & 33.9 & 22.6 \\
\hline 6 & 1 & 25.0 & 14.1 \\
\hline 6 & 1 & 48.1 & 10.2 \\
\hline 30 & 29 & 68.2 & 32.2 \\
\hline 5 & 1 & 28.8 & 4.6 \\
\hline 4 & 3 & 24.6 & 8.2 \\
\hline 34 & 27 & 40.4 & 16.9 \\
\hline 1 & 1 & 81.0 & - \\
\hline 24 & 94 & 27.9 & 10.6 \\
\hline 3 & 11 & 4.2 & 2.2 \\
\hline 3 & 10 & 3.6 & 1.8 \\
\hline 8 & 5 & 29.1 & 13.1 \\
\hline 4 & 25 & 12.5 & 11.4 \\
\hline 16 & 13 & 34.7 & 17.6 \\
\hline 8 & 6 & 44.7 & 12.2 \\
\hline 2 & 1 & 29.5 & 2.1 \\
\hline \multirow[t]{2}{*}{26} & & 37.1 & 15.6 \\
\hline & 9 & & \\
\hline 5 & 3 & 9.6 & 18.7 \\
\hline 1 & 6 & 12.0 & - \\
\hline 18 & 81 & 22.7 & 8.3 \\
\hline 18 & 34 & 32.5 & 23.3 \\
\hline 14 & 3 & 67.3 & 31.9 \\
\hline 1 & 1 & 12.0 & - \\
\hline 19 & 45 & 65.1 & 33.1 \\
\hline 3 & 2 & 73.9 & 12.7 \\
\hline 5 & 3 & 34.5 & 22.9 \\
\hline
\end{tabular}

included in the 
Table 4. Comparison of rank order of taxa hydrological optima with results of previous studies. Taxa are ranked from 1 in the wettest locations to 8 in the driest.

\begin{tabular}{|c|c|c|c|c|c|c|c|}
\hline Location & Reference $^{1}$ & $\begin{array}{l}\text { Centropyxis } \\
\text { aculeata }^{2}\end{array}$ & $\begin{array}{l}\text { Hyalosphen } \\
\text { ia papilio }\end{array}$ & $\begin{array}{l}\text { Heleopera } \\
\text { petricola }\end{array}$ & $\begin{array}{l}\text { Amphitrem } \\
\text { a flavum }\end{array}$ & $\begin{array}{l}\text { Nebela } \\
\text { tincta }^{3}\end{array}$ & $\begin{array}{l}\text { Assulina } \\
\text { seminulum }\end{array}$ \\
\hline Turkey & This study & 1 & 2 & 3 & 4 & 5 & 6 \\
\hline Alaska, USA & Payne et al. (2006) & 3 & 2 & 4 & 1 & 6 & 7 \\
\hline United Kingdom & $\begin{array}{l}\text { Woodland et al. } \\
(1998)\end{array}$ & 1 & 2 & 7 & 3 & 4 & 5 \\
\hline $\begin{array}{l}\text { Jura Mountains, } \\
\text { France and } \\
\text { Switzerland }\end{array}$ & Mitchell et al. (1999) & 3 & 2 & 5 & 1 & 6 & 4 \\
\hline $\begin{array}{l}\text { Newfoundland, } \\
\text { Canada }\end{array}$ & $\begin{array}{l}\text { Charman and Warner } \\
(1997)\end{array}$ & 1 & 8 & 2 & 3 & 4 & 5 \\
\hline $\begin{array}{l}\text { Minnesota, USA } \\
\text { and Ontario, } \\
\text { Canada }\end{array}$ & $\begin{array}{l}\text { Warner and Charman } \\
\text { (1994) }\end{array}$ & 3 & 1 & 4 & 2 & 5 & 6 \\
\hline Ontario, Canada & $\begin{array}{l}\text { Charman and Warner } \\
(1992)\end{array}$ & 3 & 1 & 4 & 2 & 6 & 8 \\
\hline Finland & Tolonen et al. (1994) & 4 & 3 & 2 & 1 & 8 & 5 \\
\hline Western Russia & Bobrov et al. (1999) & 6 & 3 & 2 & 1 & 5 & 4 \\
\hline Michigan, USA & Booth (2001) & 1 & 3 & 5 & 2 & 8 & 6 \\
\hline Northwest Europe & Charman et al. (2007) & 1 & 4 & 2 & 3 & 7 & 6 \\
\hline Poland & $\begin{array}{l}\text { Lamentowicz and } \\
\text { Mitchell (2005) }\end{array}$ & 1 & 3 & 4 & 2 & 5 & 6 \\
\hline
\end{tabular}

${ }^{1}$ The studies of Charman (1997) and Payne and Mitchell (2007) are excluded as they have distinctly different amoebae communities; the former is the only study in the southern hemisphere and the later is in more nutrient-rich sites. Booth (2002) does not present optima values.

${ }_{2}^{2}$ May include Centropyxis hirsuta in some studies.

${ }^{3}$ In this study similar taxa without pores were not differentiated.

Figure 1. Location of Sürmene Ağaçbaşı Yaylası site. 




Figure 2. Principal components analysis (PCA) plot of amoebae data. A) Showing samples: western sector samples shown by open squares, eastern sector samples by crosses and southern sector samples by filled squares. B) Showing species. 

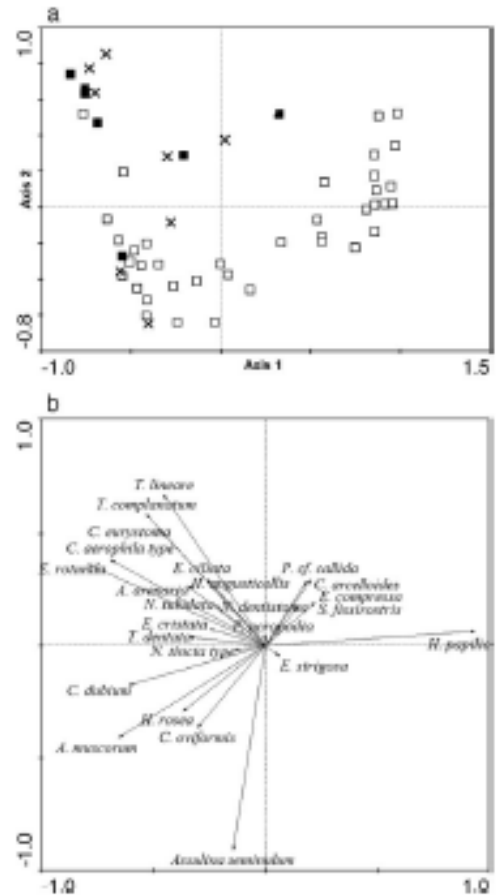

Figure 3. Observed against model predicted depth to water table (DWT) using maximum likelihood model for A) raw and B) filtered data.
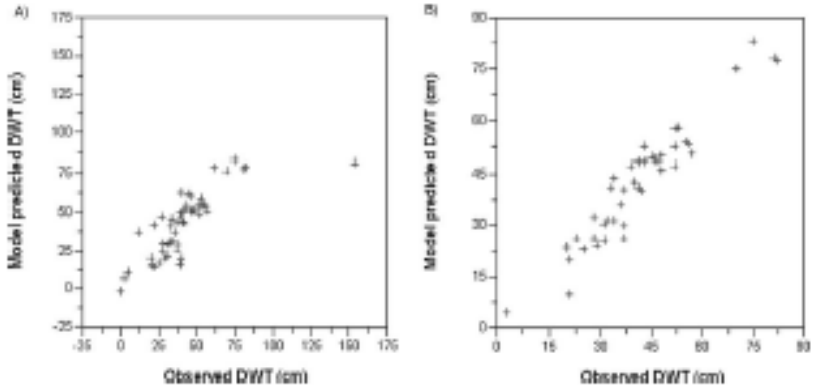

Figure 4. Relative position of selected taxa depth to water table (DWT) optima on the hydrological gradient for this and previous studies.

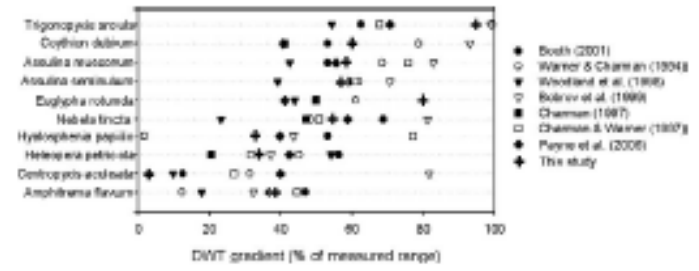

Fig 5. Palaeoecological data from cores at the Sürmene Ağaçbaşı Yaylası site. 


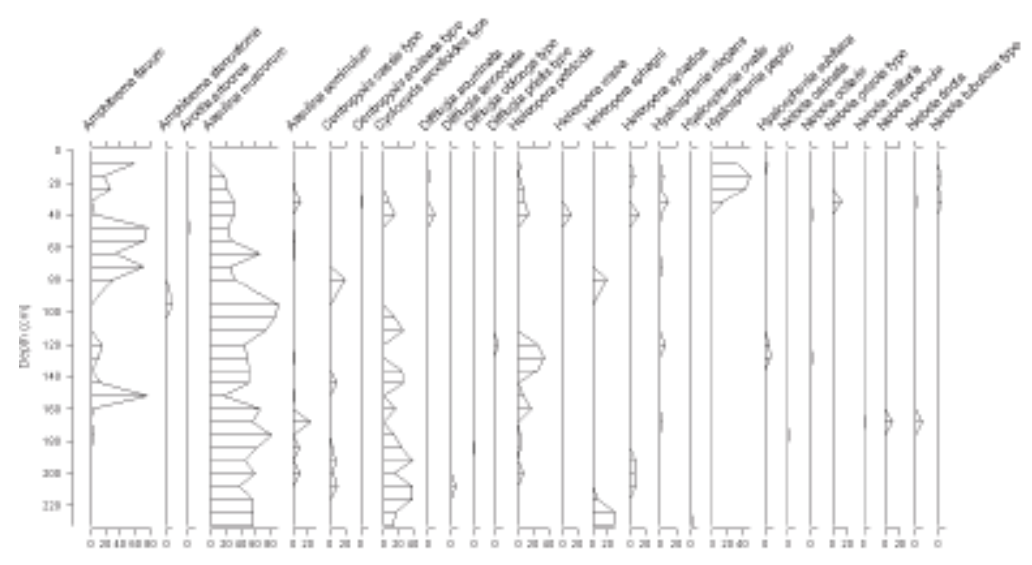

Figure 6. Testate amoebae inferred depth to water table (TI-DWT) reconstructions using the selected ML model and the WA-PLS model for this study and using the northern European model of Charman et al. (2007).



